2002s-19

\title{
Unobserved Ability and the Return to Schooling
}

\author{
Christian Belzil, Jörgen Hansen
}

Série Scientifique

Scientific Series

\section{CIRANO \\ Ceatre interuniversitaire de rocherche}

Montréal

Février 2002 


\section{CIRANO}

Le CIRANO est un organisme sans but lucratif constitué en vertu de la Loi des compagnies du Québec. Le financement de son infrastructure et de ses activités de recherche provient des cotisations de ses organisationsmembres, d'une subvention d'infrastructure du ministère de la Recherche, de la Science et de la Technologie, de même que des subventions et mandats obtenus par ses équipes de recherche.

CIRANO is a private non-profit organization incorporated under the Québec Companies Act. Its infrastructure and research activities are funded through fees paid by member organizations, an infrastructure grant from the Ministère de la Recherche, de la Science et de la Technologie, and grants and research mandates obtained by its research teams.

\section{Les organisations-partenaires / The Partner Organizations}

-École des Hautes Études Commerciales

-École Polytechnique de Montréal

-Université Concordia

-Université de Montréal

-Université du Québec à Montréal

-Université Laval

-Université McGill

-Ministère des Finances du Québec

-MRST

-Alcan inc.

- AXA Canada

-Banque du Canada

-Banque Laurentienne du Canada

-Banque Nationale du Canada

- Banque Royale du Canada

- Bell Canada

- Bombardier

- Bourse de Montréal

-Développement des ressources humaines Canada (DRHC)

-Fédération des caisses Desjardins du Québec

-Hydro-Québec

-Industrie Canada

-Pratt \& Whitney Canada Inc.

-Raymond Chabot Grant Thornton

-Ville de Montréal

(C) 2002 Christian Belzil et Jörgen Hansen. Tous droits réservés. All rights reserved. Reproduction partielle permise avec citation du document source, incluant la notice (C).

Short sections may be quoted without explicit permission, if full credit, including (C) notice, is given to the source.

Les cahiers de la série scientifique (CS) visent à rendre accessibles des résultats de recherche effectuée au CIRANO afin de susciter échanges et commentaires. Ces cahiers sont écrits dans le style des publications scientifiques. Les idées et les opinions émises sont sous l'unique responsabilité des auteurs et ne représentent pas nécessairement les positions du CIRANO ou de ses partenaires.

This paper presents research carried out at CIRANO and aims at encouraging discussion and comment. The observations and viewpoints expressed are the sole responsibility of the authors. They do not necessarily represent positions of CIRANO or its partners.

\section{ISSN 1198-8177}




\title{
Unobserved Ability and the Return to Schooling*
}

\author{
Christian Belzil $\dagger^{\dagger}$ and Jörgen Hansen
}

\begin{abstract}
Résumé / Abstract
À partir d'un échantillon tiré du National Longitudinal Survey of Youth (NLSY), nous estimons un modèle de programmation dynamique des choix d'éducation en présence d'hétérogénéité non observée dans les capacités scolaires et aptitudes sur le marché de l'emploi. L'utilité instantanée de la fréquentation scolaire ainsi que la fonction de salaire sont évaluées de façon flexible. L'hypothèse nulle que les rendements marginaux de l'éducation sont constants est catégoriquement rejetée en faveur d'une fonction de salaire convexe composée de huit segments de fonction d'approximation spline. Les rendements marginaux s'avèrent être très faibles jusqu'à la onzième année ( $1 \%$ ou moins par an), augmentent jusqu'à $3,7 \%$ pour la douzième année et dépassent les $10 \%$ pour les années 14 à 16 . Le rendement moyen augmente uniformément de $0,4 \%$ ( $7^{\text {ème }}$ année) à 4,6\% (16 ${ }^{\text {ème }}$ année). La convexité de la fonction de régression logarithmique du salaire implique que ceux qui atteignent un plus haut niveau de scolarisation obtiennent également de meilleurs rendements moyens sur le marché de l'emploi. Nous rejetons l'hypothèse nulle selon laquelle les aptitudes non observées sur le marché du travail ne sont pas corrélées avec les niveaux d'éducation atteints. Ce résultat va à l'encontre de ceux obtenus dans plusieurs études antérieures qui estimaient le rendement de l'éducation par la méthode des MCO. Nous trouvons une corrélation positive entre le niveau de scolarité atteint et les aptitudes sur le marché de l'emploi, confirmant ainsi l'existence d'un «Biais d'aptitude» positif.

We estimate a structural dynamic programming model of schooling decisions with unobserved heterogeneity in school ability and market ability on a sample taken from the National Longitudinal Survey of Youth (NLSY). Both the instantaneous utility of attending school and the wage regression function are estimated flexibly. The null hypothesis that the local returns to schooling are constant is strongly rejected in favor of a convex wage regression function composed of 8 spline segments. The local returns are very low until grade 11 (1\% per year or less), increase to $3.7 \%$ in grade 12 and exceed $10 \%$ only from grade 14 to grade 16. The average return increases smoothly from $0.4 \%$ (grade 7 ) to $4.6 \%$ (grade 16). The convexity of the log wage regression function implies that those who obtain more schooling also experience higher average returns. We strongly reject the null hypothesis that unobserved market ability is uncorrelated with realized schooling attainments, which underlies many previous studies that have used OLS to estimate the return to schooling. The correlation between realized schooling and market ability is found to be positive and is consistent with the existence of a positive "Ability Bias".
\end{abstract}

Mots-clés : Rendements de l'éducation, Programmation dynamique, Biais d'aptitude, Biais de taux d'escompte

Keywords: Return to Schooling, Dynamic Programming, Ability Bias, Discount Rate Bias JEL Classification: J2-J3

\footnotetext{
À paraître dans Econometrica/forthcoming in Econometrica

* We would like to thank Richard Blundell, James Heckman, Thierry Magnac, Jean-Marc Robin, John Rust and three anonymous referees for comments and suggestions on this version or earlier versions. Belzil thanks the Social Sciences and Humanities Research Council of Canada for generous funding. The usual disclaimer applies.

${ }^{\dagger}$ Concordia University, Cirano, and IZA.

* Concordia University, IZA, and CEPR.
} 


\section{Introduction}

In the empirical literature, it is customary to estimate the return to schooling by ordinary least squares (OLS) or Instrumental Variable (IV) techniques. ${ }^{1}$ The choice of OLS is justified only if realized schooling and unobserved labor market ability are uncorrelated. If not, OLS estimates suffer the "Ability Bias" and other estimation methods, such as IV, may be used. The volume of work devoted to the return to schooling is a good indication of the importance of this topic as perceived by economists. ${ }^{2}$ Frequently, instrumental variables (IV) techniques are applied in a context where the instrument is only weakly correlated with schooling attainments (Staiger and Stock, 1997). As a consequence, the validity of very high returns to schooling, reported in a simple regression framework, should be seriously questioned (see Manski and Pepper, 2000). ${ }^{3}$

When IV techniques are chosen, the log wage regression is usually assumed to be linear in schooling. However, there is no obvious reason to presume that the local returns to schooling are independent of grade level. Indeed, heterogeneity in any component of schooling choices (subjective discount rates, ability or specific taste for schooling) will lead to improper inference if the local returns are erroneously assumed to be constant. As individuals with lower taste for schooling tend to stop school earlier, OLS (or IV) estimates of the return to schooling, which impose equality between local and average returns at all levels of schooling, will be strongly affected by the relative frequencies of individuals with high and low taste for schooling. More precisely, if there are large differences in local returns between various grade levels, the OLS estimate (measuring an average log wage increment per year of schooling) will tend to be biased toward the local returns at schooling attainments that are the most common in the sample data. In the literature, this is referred to as the "Discount Rate Bias" 4 Estimating the

\footnotetext{
${ }^{1}$ To use the same terminology as in the reduced-form literature, the return (local) to schooling refers to the percentage wage increase per additional year of schooling. In the paper, the terms local and marginal returns may be used interchangeably. The average return refers to the slope of the straight line between the intercept and the expected log wage at a given number of years of schooling.

${ }^{2}$ A World Wide Web survey of the most recent literature indicates that, since 1970, more than 200 published articles or working papers (set in a reduced-form) have been devoted to the estimation of the return to schooling or surrounding issues. Very often, studies based on IV methods conclude that the returns to schooling can be between $20 \%$ and $40 \%$ above the OLS estimates. Reported estimates around $15 \%$ per year (for the US) are not uncommon although standard errors are typically very high. See Card (2000) for a survey.

${ }^{3}$ Manski and Pepper (2000) obtain upper bound estimates of the return to schooling from a sample taken from the NLSY. Their results cast doubts on the high returns reported in the literature.

${ }^{4}$ The term "Discount Rate Bias" is due to Lang (1993). Card (2000) conjectured that OLS (or IV) estimates will over-estimate the true return to schooling because the local return to schooling decreases with grade level and because there is a positive correlation between individual discount rates and the average return to schooling (ie: "the disadvantaged will
} 
true returns to schooling is therefore not a simple task. As unobserved taste for schooling cannot be identified in reduced-form models, investigating the relationships between school ability, market ability and the return to schooling requires researchers to use a structural dynamic discrete choice model in which the wage regression is estimated flexibly. As far as we know, this has never been done. ${ }^{5}$

In this paper, we remove this oversight. We estimate a structural dynamic programming model of schooling decisions with unobserved heterogeneity in school ability and market ability, in which the wage regression is estimated using spline techniques. The main objective of the present paper is to obtain structural estimates of the local (and average) returns to schooling in a model specification which requires neither orthogonality between schooling attainments and market ability nor linear separability between realized schooling and unobserved taste for schooling. A second objective is to obtain structural estimates of the partial correlation between realized average returns and both school and market ability, which may help understand the Discount Rate Bias. A third objective is to investigate the unconditional relationship between market ability and realized schooling attainments and evaluate the magnitude of the Ability Bias. The model is implemented on a panel of white males taken from the National Longitudinal Survey of Youth (NLSY) covering the years 1979 to 1990.

Our results reported below, cast doubt on the validity of the very high returns reported in the literature. Our estimates of the return to schooling are much below those reported in the literature and, contrary to conventional wisdom, the log wage regression is found to be convex in schooling (Card, 2000). The null hypothesis that the marginal (local) returns to schooling are constant is strongly rejected in favor of a specification where the local returns are estimated using 8 spline segments. The local returns are very low until grade 11 (1\% per year or less), increase to $3.7 \%$ in grade 12 and exceed $10 \%$ only between grade 14 and grade 16. The average return (measured from grade 7) increases smoothly from $0.4 \%$ (grade 7 ) to $4.6 \%$ (grade 16 ). For a representative individual (acquiring between 12 and 13 years of schooling), the average realized return is around 1\%. The convexity of the log wage regression function implies that, other things equal, those endowed with higher school ability experience higher average returns and those endowed with higher market ability experience lower average returns. Therefore, those who obtain more schooling also experience higher average returns. This indicates that estimates obtained from linear wage regressions may suffer a severe Discount Rate Bias. At the same time, school ability and market

experience higher average returns to schooling").

${ }^{5}$ A relatively small number of authors have estimated structural models of schooling decisions. Keane and Wolpin (1997) have used a structural dynamic programming model of schooling and occupational decisions using a cohort of the NLSY. Eckstein and Wolpin (2000) evaluate the effect of youth employment on academic performance of young Americans. Arcidiacono (2000) has estimated a dynamic model of college choices. For a seminal paper on empirical dynamic programming methods, see Rust (1986). 
ability are strongly correlated. As a consequence, the unconditional relationship between schooling attainment and market ability is ambiguous. Our simulations indicate that there is a positive correlation (0.28) between market ability and realized schooling and orthogonality is strongly rejected. This is evidence in favor of the existence of a positive Ability Bias ${ }^{6}$.

The paper is organized as follows. Section 2 is devoted to the presentation of the empirical dynamic programming model. Section 3 contains a brief description of the sample data. The main empirical results are found in Section 4. The effects of heterogeneity on the estimates of the return to schooling are presented in Section 5 and the reliability of linear wage regression models is discussed in Section 6. The robustness of the results is analyzed in Section 7. Section 8 concludes.

\section{An Empirical Dynamic Programming Model}

In this section, we introduce the empirical dynamic programming model. Every individual $i$ is initially endowed with family human capital $\left(X_{i}\right)$, innate market and school ability $\left(v_{i}^{w}\right.$ and $\left.v_{i}^{\xi}\right)$ and a rate of time preference $(\rho)$. Young individuals decide sequentially whether it is optimal or not to enter the labor market or continue accumulate human capital. Individuals maximize discounted expected lifetime utility over a finite (known) horizon $T$. Both the instantaneous utility of being in school and the utility of work are logarithmic in income. The control variable, $d_{i t}$, summarizes the stopping rule. When $d_{i t}=1$, an individual invests in an additional year of schooling at the beginning of period t. When $d_{i t}=0$, an individual leaves school at the beginning of period $t$ (to enter the labor market). Every decision is made at the beginning of the period and the amount of schooling acquired by the beginning of date $\mathrm{t}$ is denoted $S_{i t}$.

\subsection{Household Characteristics and the Utility of Attend- ing School}

When in school, individuals receive income support, denoted $\xi_{i t}$. When an individual leaves school, he looses parental support. The instantaneous utility of attending school, $U^{\text {school }}($.$) is represented by the following equation$

$$
U^{\text {school }}(.)=\ln \left(\xi_{i t}\right)=X_{i}^{\prime} \delta+\psi\left(S_{i t}\right)+v_{i}^{\xi}+\varepsilon_{i t}^{\xi}
$$

with $\varepsilon_{i t}^{\xi} \sim$ i.i.d $N\left(0, \sigma_{\xi}^{2}\right)$ and represents a stochastic utility (income) shock. The vector $X_{i}$ contains the following variables: father's education, mother's education, household income, number of siblings, family composition at age 14 and

\footnotetext{
${ }^{6}$ The magnitude of the Ability Bias is also central in the empirical literature on the time series properties of wage inequality. For a recent example, see Taber (2000).
} 
regional controls ${ }^{7}$. The term $v_{i}^{\xi}$ represents individual heterogeneity (ability) affecting the utility of attending school. It is discussed in more details below. The marginal effect of schooling level on parental transfers, $\psi($.$) , is modeled using$ spline functions.

\subsection{Interruption of schooling}

We assume that individuals interrupt schooling with exogenous probability $\zeta\left(S_{t}\right)$ and, as a consequence, the possibility to take a decision depends on a state variable $\mathrm{I}_{i t}$. When $I_{i t}=1$, the decision problem is frozen for one period. If $I_{i t}=0$, the decision can be made. The interruption state is meant to capture events such as illness, injury, travel, temporary work, incarceration or academic failure. When an interruption occurs, the stock of human capital remains constant over the period. The NLSY does not contain data on parental transfers and, in particular, does not allow a distinction in income received according to the interruption status. As a consequence, we ignore the distinction between income support while in school and income support when school is interrupted. ${ }^{8}$

\subsection{The Utility of Work and the Return to Human Cap- ital}

Once the individual has entered the labor market, he receives monetary income $w_{i t}$ (an hourly wage rate) and a yearly employment rate, $e_{i t}$. The instantaneous utility of labor market work is

$$
U^{\text {work }}(.)=\ln \left(w_{i t} \cdot e_{i t}\right) .
$$

The log wage received at time $t$, is given by

$$
\ln \left(w_{i t}\right)=\varphi_{1}\left(S_{i t}\right)+\varphi_{2} \cdot \text { Exper }_{i t}+\varphi_{3} \cdot \text { Exper }_{i t}^{2}+v_{i}^{w}+\varepsilon_{i t}^{w}
$$

where $\varepsilon_{i t}^{w} \sim$ i.i.d $N\left(0, \sigma_{w}^{2}\right)$ and represents a stochastic wage shock. $\varphi_{1}($.$) is the$ function capturing the effect of schooling on wages. The return to experience (denoted Exper $_{i t}$ ) is captured in $\varphi_{2}$ and $\varphi_{3}$ while $v_{i}^{w}$ is unobserved labor market ability.

The employment rate, $e_{i t}$, is also allowed to depend on accumulated human capital so that

$$
\ln e_{i t}^{*}=\ln \frac{1}{e_{i t}}=\kappa_{0}+\kappa_{1} \cdot S_{i t}+\kappa_{2} \cdot \text { Exper }_{i t}+\kappa_{3} \cdot \text { Exper }_{i t}^{2}+\varepsilon_{i t}^{e}
$$

\footnotetext{
${ }^{7}$ More detailed discussion is found in Belzil and Hansen (2001,a).

${ }^{8}$ When faced with a high failure probability, some individuals may spend a portion of the year in school and a residual portion out of school. As a result, identifying a real interruption from a true academic failure is tenuous. In the NLSY, we find that more than $85 \%$ of the sample has never experienced school interruption.
} 
where $\kappa_{0}$ is an intercept term, $\kappa_{1}$ represents the employment security return to schooling, both $\kappa_{2}$ and $\kappa_{3}$ represent the employment security return to experience. The random shock $\varepsilon_{i t}^{e}$ is normally distributed with mean 0 and variance $\sigma_{e}^{2}$. All random shocks $\left(\varepsilon_{i t}^{\xi}, \varepsilon_{i t}^{w}, \varepsilon_{i t}^{e}\right)$ are assumed to be independent.

\subsection{Bellman Equations}

It is convenient to summarize the state variables in a vector $\left(S_{i t}, \eta_{i t}\right)$ where $\eta_{i t}$ is itself a vector containing the interruption status $\left(I_{i t}\right)$, the utility shock $\left(\varepsilon_{i t}^{\xi}\right)$, the wage shock $\left(\varepsilon_{i t}^{w}\right)$, the employment shock $\left(\varepsilon_{i t}^{e}\right)$, and accumulated experience $\left(\right.$ Exper $\left._{i t}\right)$. We only model the decision to acquire schooling beyond 6 years (as virtually every young male in the NLSY has completed at least six years of schooling). We set $T$ to 65 years and the maximum number of years of schooling to 22. Dropping the individual subscript, the decision to remain in school, given state variables $S_{t}$ and $\eta_{t}$, denoted $V_{t}^{s}\left(S_{t}, \eta_{t}\right)$, can be expressed as

$$
\begin{gathered}
V_{t}^{s}\left(S_{t}, \eta_{t}\right)=\ln \left(\xi_{t}\right)+\beta\left\{\zeta \cdot E V_{t+1}^{I}\left(S_{t+1}, \eta_{t+1}\right)\right. \\
\left.+(1-\zeta) \cdot E \operatorname{Max}\left[V_{t+1}^{s}\left(S_{t+1}, \eta_{t+1}\right), V_{t+1}^{w}\left(S_{t+1}, \eta_{t+1}\right)\right]\right\}
\end{gathered}
$$

where $V_{t+1}^{I}\left(S_{t+1}, \eta_{t+1}\right)$ denotes the value of entering the interruption status. As we cannot distinguish between income support while in school and income support when school is interrupted, $V_{t+1}^{I}\left(S_{t+1}, \eta_{t+1}\right)$, can be expressed as follows.

$$
\begin{aligned}
& V_{t+1}^{I}\left(S_{t+1}, \eta_{t+1}\right)=\log \left(\xi_{t+1}\right)+\beta\left\{\zeta \cdot E V_{t+2}^{I}\left(S_{t+2}, \eta_{t+2}\right)\right. \\
& \left.+(1-\zeta) \cdot \operatorname{EMax}\left[V_{t+2}^{s}\left(S_{t+2}, \eta_{t+2}\right), V_{t+2}^{w}\left(S_{t+2}, \eta_{t+2}\right)\right]\right\}
\end{aligned}
$$

The value of stopping school (that is entering the labor market), $V_{t}^{w}\left(S_{t}, \eta_{t}\right)$, is given by

$$
V_{t}^{w}\left(S_{t}\right)=\ln \left(w_{i t} \cdot e_{i t}\right)+\beta E\left(V_{t+1} \mid d_{t}=0\right)
$$

where $E\left(V_{t+1} \mid d_{t}=0\right)$ is simply

$$
E\left(V_{t+1} \mid d_{t}=0\right)=\sum_{j=t+1}^{T} \beta^{j-(t+1)}\left(-\exp \left(\mu_{j}+\frac{1}{2} \sigma_{e}^{2}\right)+\varphi_{1}\left(S_{j}\right)+\varphi_{2} . \text { Exper }_{j}+\varphi_{3} . \text { Exper }_{j}^{2}\right)
$$

and represents the expected utility of working from $t+1$ until $T$. Using the terminal value and the distributional assumptions about the stochastic shocks, the probability of choosing a particular sequence of discrete choice can readily be expressed in closed-form. 


\subsection{Unobserved Ability in School and in the Market}

In our model, heterogeneity has 2 dimensions: heterogeneity in school ability (taste for schooling), $v_{i}^{\xi}$, and heterogeneity in market ability, $v_{i}^{w}$. We assume that here are $K$ types of individuals and that each type is endowed with a pair of school and market ability $\left(v_{k}^{w}, v_{k}^{\xi}\right)$ for $k=1,2 \ldots K$ and $K=6$. The distribution of unobserved ability is orthogonal to parents' background by construction and should be understood as a measure of unobserved ability remaining after conditioning on parents human capital. The probabilities of belonging to type $k, p_{k}$, are estimated using logistic transforms

$$
p_{k}=\frac{\exp \left(q_{k}\right)}{\sum_{j=1}^{6} \exp \left(q_{j}\right)}
$$

and with the restriction that $q_{6}$ equals 0 .

\subsection{Identification}

Identification of the wage return to schooling. the employment return to schooling and unobserved market ability is relatively straightforward given panel data on labor market wages and employment rates. However, given the very small amount of observations at both very low and very high levels of schooling, it is difficult to identify the local returns below grade 10 and above grade 17 . Our model being structured as a single choice dynamic model, data on both wages and schooling attainments allow us to identify the key parameters the utility of attending school. Finally, as is well known, identification of the subjective discount rate relies on the standard assumption that preferences are time additive.

\subsection{The Likelihood Function}

Constructing the likelihood function (for a given type $k$ ) is relatively straightforward. It has three components; the probability of having spent at most $\tau$ years in school $\left(L_{1 k}\right)$, the probability of entering the labor market in year $\tau+1$, at observed wage $w_{\tau+1}$ (denoted $L_{2 k}$ ) and the density of observed wages and employment rates from $\tau+2$ until 1990 (denoted $L_{3 k}$ ). $L_{1 k}$ can easily be evaluated using (4), (5) and (6), while $L_{2 k}$ can be factored as the product of a normal conditional probability times the marginal wage density. Finally $L_{3 k}$ is just the product of wage and employment rate densities. For a given type $k$, the likelihood is therefore $L_{k}=L_{1 k} \cdot L_{2 k} \cdot L_{3 k}$ and the log likelihood function to be maximized is

$$
\log L=\log \sum_{k=1}^{6} p_{k} \cdot L_{k}
$$

where each $p_{k}$ represents the population proportion of type $k$. 


\section{The Data}

The sample used in the analysis is extracted from the 1979 youth cohort of the The National Longitudinal Survey of Youth (NLSY). The NLSY is a nationally representative sample of 12,686 Americans who were 14-21 years old as of January 1, 1979. After the initial survey, re-interviews have been conducted in each subsequent year until 1996. In this paper, we restrict our sample to white males who were age 20 or less as of January 1, 1979. We record information on education, wages and on employment rates for each individual from the time the individual is age 16 up to December 31, 1990.

The original sample contained 3,790 white males. We lost about $17 \%$ of the sample due to missing information regarding family income and about $6 \%$ due to missing information regarding parents' education. The age limit and missing information regarding actual work experience further reduced the sample to 1,710. Summary statistics may be found in Table 1.

Overall, the majority of young individuals acquire education without interruption. In our sample, only 306 individuals have experienced at least one interruption. This represents only $18 \%$ of our sample and it is along the lines of results reported in Keane and Wolpin (1997). ${ }^{9}$ Given the age of the individuals in our sample, we assume that those who have already started to work full-time by 1990 (94\% of our sample), will never return to school beyond 1990. More details can be found in Belzil and Hansen (2001,a).

\section{Empirical Results}

This section is devoted to the presentation of the empirical results. The estimates of the parameters capturing the effects of household characteristics on the utility of attending school are found in Table 2 and discussed in details in Belzil and Hansen $(2001, a) .{ }^{10}$ In Section 4.1, we analyze the role of unobserved ability in explaining schooling attainments. We discuss the returns to schooling in Section 4.2 and the internal rates of return in Section 4.3. In Section 4.4, we evaluate the capacity of the model to fit the data on observed schooling attainments.

\footnotetext{
${ }^{9}$ Overall, interruptions tend to be quite short. Almost half of the individuals (45\%) who experienced an interruption, returned to school within one year while $73 \%$ returned within 3 years. More details may be found in Belzil and Hansen (2000,a).

${ }^{10}$ The estimates indicate that the utility of attending school increases with the level of human capital in the household. The incidence of schooling interruption is found to be 0.0749 and indicates that, on average, $7.5 \%$ of young individuals interrupt school in a given year. The estimate of the subjective discount rate, 0.0299, appears quite reasonable and is close to estimates reported in the financial economics literature (see Kocherlakota, 1996).
} 


\subsection{The Role of Unobserved Ability in Explaining School- ing Attainments}

The importance of unobserved ability is illustrated in Table 3 . The intercept terms of the utility of attending school $\left(v^{\xi}\right)$ range from -0.7318 (type 1) to -1.4904 (type 6). The intercept terms of the wage function $\left(v^{w}\right)$ range from 2.1345 (type 1) to 1.0816 (type 6 ). There is clear evidence that those endowed with high school ability are also endowed with high market ability. Both in ascending order of school ability and market ability, the various types can be ranked as follows, type 1 , type 3 , type 2 , type 5 , type 4 and type 6 . The associated type probabilities are as follows; 0.0541 (type 1), 0.2525 (type 2), 0.1566 (type 3), 0.3022 (type 4), 0.1249 (type 5) and 0.1098 (type 6). Type 1 , type 3 and type 2 individuals appear particularly more able than other types. A deeper analysis of the correlation between ability and realized schooling attainments is delayed to Section 5 .

\subsection{The Return to Schooling}

The wage and employment returns to schooling are found in Table 4A. Our findings are consistent with what is normally expected; education reduces unemployment and raises wages. ${ }^{11}$ We note that the flexibility of our estimation method discloses the weakness of model specifications where the return to schooling is captured in a single parameter. The level of significance of all spline estimates (as indicated by the standard errors) indicate that, at all 8 knots joining the various segments, equality of the local returns across successive segments is strongly rejected. ${ }^{12}$ This implies a clear rejection of the model with constant marginal returns to schooling. Our estimates of the local returns, summarized in Table $4 \mathrm{~A}$, indicate that the marginal returns are generally increasing with the level of schooling up to grade 14 . The local returns to college training are substantially higher than the returns to high-school education. Indeed, schooling has practically no value until grade 12 . Until grade 10, the local return is below $1 \%$ per year $(0.4 \%)$. It increases to $1.2 \%$ in grade 11 and to $3.7 \%$ in grade 12 . Beyond high school graduation, the local return starts to increase substantially. The local return increases to $6.0 \%$ in grade 13 and $12.7 \%$ in grade 14 . After a drop at grade 15 (the local return is around $10.7 \%$ ), the return to grade 16 raises to $12.2 \%$. In subsequent years (corresponding to graduate training), the local returns are es-

\footnotetext{
${ }^{11}$ The estimate of the effects of education (-0.1331) and actual experience (-0.0156) on the log inverse employment rate indicate that there is a clear negative (positive) significant relationship between individual unemployment (employment) rates and human capital. The effect of experience squared on the log employment rate is found to be very small (and insignificant).

${ }^{12}$ In practice, we kept a spline at each grade level where the equality between successive returns is rejected. In the end, we found that as many as 8 splines were necessary to summarize the log wage regression function accurately.
} 
timated to be $8.8 \%$ per year. Until college graduation, and except for the lower local return in grade 15 , the log wage regression equation is convex in schooling. ${ }^{13}$ This is contrary to what is often postulated (see Card, 2000). ${ }^{14}$

The variations in the local returns to schooling illustrate the distortions introduced in a model built on the assumption that the local returns to schooling are constant. As the local and average returns are identical in a linear model, it is also important to compare our estimates of the average return with those obtained in the literature. The average returns are also found in Table 4A. Although the average returns are naturally computed from grade 7 , they may also be measured from the beginning of the period over which an individual can legally leave school (around grade 10). The low returns at lower level of schooling, along with the sharp increase at grades 12,13, 14 and 16, imply a relatively smooth increase in the average return to schooling. At college graduation, the average return (measured from grade 7 ) is around $4.6 \%$ per year. In the population, the realized average returns are much smaller as a typical individual would obtain between 12 and 13 years of schooling. In grade 12, the average return is less than $1 \%$ per year $(0.71 \%)$ while, in grade 13 , the average return is $1.47 \%$. When measured from grade 7 , the average return at high-school graduation is $1.8 \%$ per year and it is $6.7 \%$ at college graduation.

Finally, the estimates for actual experience (0.0880) and its square (-0.0030) show that our panel is sufficiently long to capture concavity in age-earnings profiles. The high return to experience is not really surprising for young workers. To summarize, our estimates of the return to schooling are much below those reported in the reduced-form literature, and interestingly, they can also be reconciled with the relatively weak correlation between education and growth found in the empirical literature. ${ }^{15}$

\footnotetext{
${ }^{13}$ While it might be tempted to impute the convexity to the assumption that the returns are homogeneous in the population, the results reported in a companion paper (Belzil and Hansen, $2000 \mathrm{~b})$ indicate that it is not the case.

${ }^{14}$ We have also estimated the model under alternative specifications (a finite mixture version without household human capital variables as well as a version where type probabilities are also function of observable characteristics) but found practically identical results. Another estimation strategy would be to include AFQT scores in the intercept terms of both the utility of attending school and the log wage regression function. However, this approach could lead to an understatement of the effects of schooling on wages, if AFQT scores are themselves explained by schooling.

${ }^{15}$ Manski and Pepper (2000) also conclude that the true returns are most probably below those reported in the literature. Rosenzweig and Wolpin (2000) argue that estimates of the return to schooling which ignore post-schooling human capital investments are likely to be unreliable. For a review of the empirical growth literature, see Topel, 2000.
} 


\subsection{Internal Rate of Return to Four Year College}

Using a measure of tuition for 4 year colleges, it is also possible to evaluate the internal rate of return; that is the rate of return that equates the discounted sum of direct costs and foregone wages with the increased wages due to completing college versus high school. It will provide key insights about the mechanics of the model and will enable us to compare the higher local returns to post high-school education with rates of return on other types of investments. Over the period covered by the data, the average tuition in the US was around $\$ 3,400$ per year (in $1990 \$) .{ }^{16}$ While other direct costs are unknown, the tuition cost is clearly a lower bound for the total cost of attending college. We have computed 2 different internal rates of return; one for a yearly cost of $\$ 5,000$ per year and one for a cost of $\$ 10,000$. This difference can account for factors such as college quality. In both cases, we have computed a type specific internal rate of return as well as a population average. These are found in Table 4B. The internal rates range from $5 \%$ to $8 \%$ in the $\$ 5,000$ scenario and from $3 \%$ to $6 \%$ in the $\$ 10,000$ scenario. Not surprisingly, we find that internal rates are higher for those with high ability (type 1, type 3 and type 2) than for those with low ability (type 4, type 5 and type 6). Overall, these internal rates are comparable to rates of return on risky investments (Kocherlakota, 1996).

\subsection{Goodness of Fit}

One of the most distinctive features of observed schooling attainments, is the very uneven distribution across various grade levels. Actual frequencies are presented in Table 5 . They indicate that around $60 \%$ of young males have completed either 12 or 16 years of schooling. The predicted frequencies are also shown in Table 5. The model is able to predict large frequencies at grade 12 and grade 16 . When compared to the actual frequencies, the predictions appear quite accurate. ${ }^{17}$

\section{Evaluating the Effects of Heterogeneity on the Returns to Schooling}

As a next step, we computed the partial correlations between both forms of ability and realized schooling attainments generated by the parameters of the model. These partial correlations represent an alternative way to illustrate the conflict between school and market ability and are useful in order to understand the Discount Rate Bias. In view of the large number of reduced-form estimates based on the assumption that the returns to schooling may be estimated using OLS, it

\footnotetext{
${ }^{16}$ See Light and Strayer (2000).

${ }^{17}$ The capacity of the model to fit data on lifetime employment rates is discussed in Belzil and Hansen $(2000, a)$.
} 
is also interesting to investigate the unconditional relationship between market ability and the average returns as well as the correlation between market ability and realized schooling attainments. While there is no obvious way of measuring the bias in the local returns caused by assuming orthogonality between market ability and the regression function in our model, the correlation between unobserved market ability and realized schooling would still provide a good indication of the importance of the Ability Bias.

The correlations are summarized in Table 6 . The correlation between ability in school and ability in the market, $\operatorname{Corr}\left(v_{i}^{w}, v_{i}^{\xi}\right)$, is found to be high (0.95). Holding market ability constant, we find a strong positive correlation between average returns and school ability, $\operatorname{Corr}\left(v_{i}^{\xi},\left.\frac{\varphi\left(S_{i}\right)}{S_{i}}\right|_{v_{i}^{w}=\bar{v}^{w}}\right)=0.80$. This positive correlation implies that, holding market ability and family background variables constant, those endowed with higher school ability will also experience higher average returns. This is an illustration of the discount rate bias. As expected, and contrary to school ability, the partial correlation between market ability and schooling is negative, $\operatorname{Corr}\left(v_{i}^{w},\left.\frac{\varphi\left(S_{i}\right)}{S_{i}}\right|_{v_{i}^{\xi}=\bar{v}^{\xi}}\right)=-0.84$.

Our estimates of the correlation between unobserved market ability and average returns, $\operatorname{Corr}\left(v_{i}^{w}, \frac{\varphi\left(S_{i}\right)}{S_{i}}\right)$, and the correlation between unobserved market ability and realized schooling, $\operatorname{Corr}\left(v_{i}^{w}, S_{i}\right)$, are both positive. They are respectively equal to 0.23 and 0.28 and are significant at the $1 \%$ level. Orthogonality between market ability and realized schooling is therefore strongly rejected. This provides evidence in favor of the existence of a strong positive ability bias. Estimation methods based on the maintained assumption that realized schooling and market ability are orthogonal are therefore questionable. They will clearly lead to an over-estimation of the average return to schooling.

\section{Can a Single Parameter Summarize the Av- erage Return Accurately?}

Estimating the return to schooling and experience in a reduced-form framework is particularly difficult since, in general, schooling and experience cannot be separated linearly from unobserved ability components. To see this, re-write the wage regression function as

$\ln \left(w_{i t}\right)=\varphi_{1}\left(S_{i t}\left(v_{i}^{\xi}, v_{i}^{w}\right)\right)+\varphi_{2} \cdot \operatorname{Exper}_{i t}\left(v_{i}^{\xi}, v_{i}^{w}\right)+\varphi_{3} \cdot \operatorname{Exper}_{i t}^{2}\left(v_{i}^{\xi}, v_{i}^{w}\right)+v_{i}^{w}+\varepsilon_{i t}^{w}$

In the literature, it is usually assumed that $\varphi_{1}($.$) is linear in schooling and that S_{i t}$ and $v_{i}^{\xi}$ are linearly separable. For those who seek to estimate the true returns in an instrumental variable framework, these assumptions are particularly crucial. If the linear log wage regression is not supported by the data and the form of the wage regression function is unknown, the estimation method is more complicated 
(see Newey, Powell and Vella, 1999, for a static labor supply example and Blundell and Powell, 2000, for a survey). Furthermore, if unobserved ability and schooling cannot be separated linearly, this is even more difficult (see Heckman and Vitlacyl, 2000). However, while a linear regression framework is incapable of capturing changes in the local returns to schooling, it might be argued that it can still estimate the average return accurately.

In Table 7, we compare the maximum likelihood estimates of the average return to schooling obtained from the structural dynamic programming model to those obtained using OLS estimates. We considered the standard OLS estimate as well as the OLS estimate with splines (with the same spline segments as in the structural dynamic programming model). We report the estimates of the average return to schooling at high school graduation (grade 12) and at college graduation (grade 16). For both of these, we report values measured from grade 7 and values measured from grade 10 .

The incapacity of OLS estimates to capture the average return over the entire range is well documented. In the 1990 cross-section of the NLSY, the OLS estimate of the return to schooling is $0.0995 .{ }^{18}$ When the OLS regression is composed of 8 splines, the average returns measured from grade 7 are equal to $9.71 \%$ in grade 12 and $11.29 \%$ in grade 16 . When measured from grade 10 , the average returns are $8.66 \%$ (grade 12) and $9.42 \%$ (grade 16). As a comparison, our structural estimates of the average return at high school graduation $(0.71 \%)$ and at college graduation (4.6\%), measured from grade 7 , are much below the OLS estimates. This is also true of those average returns measured from grade 10 (1.77\% in grade 12 and $6.69 \%$ in grade 16). Evidently, estimation methods that do not allow for a flexible estimation of the local returns to schooling will lead to unreliable estimates of both the local and the average returns to schooling.

\section{Robustness and Alternative Specifications}

At this stage, it is natural to investigate the robustness of the results. In our model, the effects of parents' human capital are asymmetric: household background variables affect the utility of attending school but do not affect labor market skills per se. This assumption might be questioned. To evaluate the sensitivity of the results, we estimated other model specifications which allow for a more symmetric treatment of family background variables. In particular, and consistent with Keane and Wolpin (1997) and Eckstein and Wolpin (1999), we estimated a finite mixture version of the model (with 6 unknown types) which ignores data on household characteristics. In this model specification, asymmetry is obviously not an issue. The flexibility of the specification allows for any arbitrary correlation between the utility of attending school and market ability. The estimates of the wage regression function are found in Table 8.

\footnotetext{
${ }^{18}$ When OLS is applied to the entire panel, the estimate is 0.0998 .
} 
There is overwhelming evidence that the basic results (the low returns and the convexity of the wage regression) are in no way affected by the treatment of family background variables, as indicated by the local and average returns. Generally speaking, the returns obtained in a mixture model are only slightly higher than those obtained with parents' background, especially until grade 14 . As before, the returns to schooling are low until high school graduation $(4.8 \%$ in grade 12) and increase significantly in grade 14 (to reach $14.5 \%$ ). The local return in grade $16(11 \%)$ is however lower than in the model using parents' background variables. The high degree of convexity of the wage regression is therefore very robust. Other parameter estimates as well as a more in-depth discussion may be found in Belzil and Hansen (2000,a).

We have also estimated another version of the model where father's education, mother's education, household income and number of siblings affect both the utility of attending school and the wage regression equation (the rest of the variables still affect the utility of attending school) and where the employment equation is affected by unobserved heterogeneity ( 6 individual specific intercept terms). The returns to schooling have been found to be generally lower ( $2 \%$ in grade 12) but the wage regression function still displays a high degree of convexity (the local return at college graduation is $11.7 \%$ ). Not surprisingly, the effect of family background on the utility of attending school has been found to be much stronger than on wages. This issue, as well as other matters that are not directly related to the estimation of the returns to schooling, are discussed in details in a companion paper (Belzil and Hansen, 2001d).

\section{Conclusion}

We have estimated a structural dynamic programming model of schooling decisions in which individuals are heterogeneous with respect to ability in school and ability in the labor market. The rich specification of the model has allowed us to estimate the true return to schooling without assuming orthogonality between labor market ability and schooling attainments and to obtain structural estimates of various correlations between school ability, market ability and realized schooling attainments.

We find that the local returns are very small at low levels of schooling and increase significantly beyond high school graduation. Indeed, schooling has practically no value until high school graduation. We also find that a linear wage regression is severely mis-specified (the estimates suffer a severe discount rate bias) and that, in general, any regression model (whether linear or non-linear), estimated under the assumption that realized schooling and market ability are orthogonal, suffers a positive ability bias. The results are very robust. A finite mixture model (with 6 types) ignoring data on parents' background as well as a model specification in which parents' human capital affect both labor market 
ability and the utility of attending school gave very similar results. The basic findings (the low returns to schooling and the very high degree of convexity of the wage regression) are in no way related to the treatment of household background variables.

Overall, our results cast serious doubts on the validity of most results reported in the empirical labor economics literature. First, OLS estimates of the return to schooling that depend on the assumption that endogenous schooling attainment is orthogonal to unobserved determinants of wages are therefore most likely unreliable. They can seriously over-estimate the average return to schooling. Second, the convexity of the log wage regression function, along with the non-separability (linear) of realized schooling and abilities, imply that standard IV techniques are also ill-equipped to tackle the estimation of the return to schooling. As it stands now, the development of non-parametric (or semi-parametric) econometric models with endogenous regressors is a major topic of ongoing research (see Blundell and Powell, 2000). These techniques are certainly not used widely by labor economists and, as a consequence, the validity of the results already reported in the literature can be questioned seriously.

As is done in most of the literature, we have assumed that differences in market ability can be captured in the intercept of the log wage regression function and that individual differences in realized returns to schooling are explained by non-linearities in the wage regression function. This is an ad-hoc assumption. More able individuals may also have a higher return to schooling as well as a higher return to experience. However, confronting a non-linear (non-parametric) wage regression to a random coefficient wage regression is difficult. In panel data, individual wages are usually observed for a fixed level of schooling. Crosssectional heterogeneity and non-linearities in the returns to schooling are difficult to identify separately. As a consequence, the empirical investigation of more general models in which market ability heterogeneity affects both the returns to schooling and the return to experience, is a promising avenue for future research. ${ }^{19}$

\section{References}

[1] Arcidiacono, Peter (2000) "Option Values, College Quality, and Earnings: A Dynamic Model of College and Major Choice" Working Paper, Duke University.

[2] Belzil, Christian and Hansen, Jörgen (2000,a) "Unobserved Ability and the Return to Schooling" Working Paper, Concordia University.

\footnotetext{
${ }^{19}$ As far as we know, Belzil and Hansen $(2000, b)$ is the only attempt to allow simultaneously for non-linearities and cross-sectional heterogeneity in the returns to schooling. See Heckman and Vytlacil (1998) and Belzil and Hansen (2000,c) for a discussion of the log wage regression model set in a linear random coefficient framework.
} 
[3] Belzil, Christian and Hansen, Jörgen (2000,b) "Heterogeneous Returns to Human Capital and Dynamic Self-Selection" Working Paper, Concordia University and Cirano.

[4] Belzil, Christian and Hansen, Jörgen (2000,c) "A Structural Analysis of the Correlated Random Coefficient Wage Regression Model" Working Paper, Concordia University.

[5] Belzil, Christian and Hansen, Jörgen (2001,d) "Estimating the Intergenerational Education Correlation using a Dynamic Programming Model" Working Paper, Concordia University and Cirano.

[6] Blundell, Richard and James Powell (2000) "Endogeneity in Non-Parametric and Semi-Parametric Regression Models" Paper presented at the 2000 World Congress of the Econometric Society"

[7] Card, David (2000) "The Causal Effect of Education on Earnings" Handbook of Labor Economics, edited by David Card and Orley Ashenfelter, NorthHolland Publishers.

[8] Eckstein, Zvi and Kenneth Wolpin (1999) "Youth Employment and Academic Performance in High School", Econometrica 67 (6), 1295-1339.

[9] Heckman, James and E. Vytlacil (1998) "Instrumental Variables Methods for the Correlated Random Coefficient Model", Journal of Human Resources, 33, (4), 974-987

[10] Keane, Michael P. and Wolpin, Kenneth (1997) "The Career Decisions of Young Men" Journal of Political Economy, 105 (3), 473-522.

[11] Kocherlakota, Narayana (1996) "The Equity Premium: It's Still a Puzzle" Journal of Economic Literature" 24 (1), 42-71.

[12] Lang, Kevin (1993) "Ability Bias, Discount Rate Bias and the Return to Education" Unpublished Discussion Paper, Department of Economics, Boston University.

[13] Light, Audrey and Wayne Strayer (2000) "Determinants of College Completion: School Quality or student Ability", Journal of Human Resources, 35 (2), 299-332.

[14] Manski, Charles and John Pepper (2000) "Monotone Instrumental Variables: with an Application to the Returns to Schooling" Econometrica, 68 (4), 9971013 
[15] Newey, Whitney, James L. Powell and Francis Vella (1999) "Nonparametric estimation of a Triangular Simultaneous Equation System" Econometrica, 67 (3), 565-604.

[16] Rosenzweig Mark and K.Wolpin (2000) "Natural Natural Experiments in Economics" Journal of Economic Literature, December, 827-74.

[17] Rust, John (1987) "Optimal Replacement of GMC Bus Engines: An Empirical Analysis of Harold Zurcher" Econometrica, 55 (5), 999-1033.

[18] Staiger, Douglas and James H. Stock (1997), "Instrumental Variables Regression with Weak Instruments" Econometrica, 65: 557-586.

[19] Taber, Christopher (2000) "The Rising College Premium in the Eighties: Return to College or Return to Unobserved Ability", forthcoming in Review of Economic Studies.

[20] Topel, Robert (2000) "Labor Markets and Economic Growth", Handbook of Labor Economics, edited by David Card and Orley Ashenfelter, NorthHolland Publishers. 
Table 1 - Descriptive Statistics

\begin{tabular}{|l|l|l|l|}
\hline & Mean & St dev. & \# of individuals \\
\hline Family Income/1000 & 36,904 & 27.61 & 1710 \\
\hline father's educ & 11.69 & 3.47 & 1710 \\
\hline mother's educ & 11.67 & 2.46 & 1710 \\
\hline \# of siblings & 3.18 & 2.13 & 1710 \\
\hline prop. raised in urban areas & 0.73 & - & 1710 \\
\hline prop. raised in south & 0.27 & - & 1710 \\
\hline prop in nuclear family & 0.79 & - & 1710 \\
\hline Schooling completed (1990) & 12.81 & 2.58 & 1710 \\
\hline \# of interruptions & 0.06 & 0.51 & 1710 \\
\hline duration of interruptions (year) & 0.43 & 1.39 & 1710 \\
\hline wage 1979 (hour) & 7.36 & 2.43 & 217 \\
\hline wage 1980 (hour) & 7.17 & 2.74 & 422 \\
\hline wage 1981 (hour) & 7.18 & 2.75 & 598 \\
\hline wage 1982 (hour) & 7.43 & 3.17 & 819 \\
\hline wage 1983 (hour) & 7.35 & 3.21 & 947 \\
\hline wage 1984 (hour) & 7.66 & 3.60 & 1071 \\
\hline wage 1985 (hour) & 8.08 & 3.54 & 1060 \\
\hline wage 1986 (hour) & 8.75 & 3.87 & 1097 \\
\hline wage 1987 (hour) & 9.64 & 4.44 & 1147 \\
\hline wage 1988 (hour) & 10.32 & 4.89 & 1215 \\
\hline wage 1989 (hour) & 10.47 & 4.97 & 1232 \\
\hline wage 1990 (hour) & 10.99 & 5.23 & 1230 \\
\hline Experience 1990 (years) & 8.05 & 11.55 & 1230 \\
\hline
\end{tabular}

Note: Family income and hourly wages are reported in 1990 dollars. Family income is measured as of May 1978. The increasing number of wage observations is explained by the increase in participation rates. 
Table 2

The Utility of Attending School, Subjective Discount Rates and Interruption Probabilities

\begin{tabular}{|l|c|c|}
\hline & & \\
\hline & Parameter & Std error \\
\hline Utility in School & & \\
\hline Father's Educ & 0.0094 & 0.0011 \\
\hline Mother's Educ & 0.0070 & 0.0012 \\
\hline Family Income/1000 & 0.0007 & 0.0001 \\
\hline Nuclear Family & 0.0204 & 0.0056 \\
\hline Siblings & -0.0071 & 0.0012 \\
\hline Rural & -0.0058 & 0.0048 \\
\hline South & -0.0176 & 0.0050 \\
\hline Stand.Dev. $\left(\sigma_{\xi}\right)$ & 0.2251 & 0.0160 \\
\hline Educ. Splines & & \\
\hline$\delta_{7-10}$ & -0.0743 & 0.0133 \\
\hline$\delta_{11}$ & -0.0494 & 0.0120 \\
\hline$\delta_{12}$ & -1.1676 & 0.0190 \\
\hline$\delta_{13}$ & 0.2486 & 0.0293 \\
\hline$\delta_{14}$ & 1.4286 & 0.0345 \\
\hline$\delta_{15}$ & -0.1151 & 0.0208 \\
\hline$\delta_{16}$ & 0.3001 & 0.0209 \\
\hline$\delta_{17-\text { more }}$ & -0.7227 & 0.0168 \\
\hline Interruption Prob. & 0.0749 & 0.0031 \\
\hline Discount Rate & 0.0299 & 0.0009 \\
\hline & & \\
\hline mean log Likelihood & & -13.9957 \\
\hline & & \\
\hline & & \\
\hline & & \\
\hline & & \\
\hline
\end{tabular}


Table 3

The Distribution of Unobserved Ability

\begin{tabular}{|c|c|c|c|c|}
\hline & & & Param. St Error & Rankings \\
\hline \multirow[t]{3}{*}{ Type 1} & $v_{1}^{\xi}$ & School ab. & $-0.7318(0.0154)$ & 1 \\
\hline & $v_{1}^{w}$ & Market ab. & $2.1395(0.0199)$ & 1 \\
\hline & $q_{1}$ & intercept & $-0.7082(0.0021)$ & - \\
\hline \multirow[t]{3}{*}{ Type 2} & $v_{2}^{\xi}$ & School ab. & $-1.1021(0.0171)$ & 3 \\
\hline & $v_{2}^{w}$ & Market ab. & $1.6787(0.0133)$ & 3 \\
\hline & $\mathrm{q}_{2}$ & intercept & $0.8329(0.0449)$ & - \\
\hline \multirow[t]{3}{*}{ Type 3} & $v_{3}^{\xi}$ & School ab. & $-0.8785(0.0146)$ & 2 \\
\hline & $v_{3}^{w}$ & Market ab. & $1.9136(0.0173)$ & 2 \\
\hline & $\mathrm{q}_{3}$ & intercept & $0.3551(0.0411)$ & - \\
\hline \multirow[t]{3}{*}{ Type 4} & $v_{4}^{\xi}$ & School ab. & $-1.3206(0.0202)$ & 5 \\
\hline & $v_{4}^{w}$ & Market ab. & $1.3774(0.0115)$ & 5 \\
\hline & $q_{4}$ & intercept & $1.0127(0.0038)$ & - \\
\hline \multirow[t]{3}{*}{ Type 5} & $v_{5}^{\xi}$ & School ab. & $-1.1815(0.0193)$ & 4 \\
\hline & $v_{5}^{w}$ & Market ab. & $1.5488(0.0082)$ & 4 \\
\hline & $q_{5}$ & intercept & $0.1291(0.0230)$ & - \\
\hline \multirow[t]{4}{*}{ Type 6} & $v_{6}^{\xi}$ & School ab. & $-1.4904(0.0215)$ & 6 \\
\hline & $v_{6}^{w}$ & Market ab. & $1.0816(0.0162)$ & 6 \\
\hline & $q_{6}$ & intercept & 0.0 (normalized) & - \\
\hline & & & & \\
\hline
\end{tabular}

Note: The type probabilities are estimated using a logistic transform. The resulting probabilities are 0.0541 (type 1), 0.2525 (type 2), 0.1566 (type 3), 0.3022 (type 4), 0.1249 (type 5) and 0.1098 (type 6). 
Table 4A

The Return to Schooling

\begin{tabular}{|c|c|c|c|c|}
\hline & Parameter & & & \\
\hline & ( st. error) & & & \\
\hline \multirow{2}{*}{\multicolumn{5}{|c|}{ Employment }} \\
\hline & & & & \\
\hline Intercept & $-2.8173(0.0115)$ & & & \\
\hline Schooling & $-0.1309(0.0029)$ & & & \\
\hline Experience & $-0.0158(0.0024)$ & & & \\
\hline experience $^{2}$ & $0.0001(0.0000)$ & & & \\
\hline$\sigma_{e}^{2}$ & $1.4858(0.0102)$ & & & \\
\hline \multicolumn{5}{|l|}{ Wages } \\
\hline$\sigma_{w}^{2}$ & $0.2881(0.0023)$ & & & \\
\hline Experience & $0.0884(0.0025)$ & & & \\
\hline \multirow[t]{4}{*}{ experience $^{2}$} & $-0.0029(0.0002)$ & & & \\
\hline & \multicolumn{4}{|c|}{ Wage Returns to Schooling } \\
\hline & & & & \\
\hline & Splines & Local & Average & Average \\
\hline Grade & & & (from grade 7 ) & (from grade 10) \\
\hline grade7-10 & $0.0040(0.0012)$ & 0.0040 & 0.0040 & 0.0040 \\
\hline grade11 & $0.0080(0.0019)$ & 0.0120 & 0.0056 & 0.0080 \\
\hline grade12 & $0.0252(0.0025)$ & 0.0372 & 0.0071 & 0.0177 \\
\hline grade13 & $0.0227(0.0019)$ & 0.0599 & 0.0147 & 0.0280 \\
\hline grade14 & $0.0670(0.0023)$ & 0.1269 & 0.0287 & 0.0478 \\
\hline grade15 & $-0.0195(0.0035)$ & 0.1074 & 0.0374 & 0.0577 \\
\hline grade16 & $0.0148(0.0033)$ & 0.1222 & 0.0459 & 0.0669 \\
\hline grade17+ & $-0.0345(0.0027)$ & 0.0877 & 0.0506 & 0.0696 \\
\hline
\end{tabular}


Table 4B

Internal Rate of Returns for a 4 Year College

\begin{tabular}{|l|c|c|}
\hline & & \\
\hline Types & yearly cost $(\mathbf{\$ 1 9 9 0 )}$ & yearly cost $\mathbf{( \$ 1 9 9 0 )}$ \\
\hline & $\$ \mathbf{5 0 0 0}$ & $\mathbf{\$ 1 0 , 0 0 0}$ \\
\hline & & \\
\hline type $\mathbf{1}$ & $8.4 \%$ & $6.2 \%$ \\
\hline type 2 & $7.0 \%$ & $4.8 \%$ \\
\hline type $\mathbf{3}$ & $7.7 \%$ & $5.5 \%$ \\
\hline type $\mathbf{4}$ & $6.0 \%$ & $3.9 \%$ \\
\hline type $\mathbf{5}$ & $6.6 \%$ & $4.5 \%$ \\
\hline type $\mathbf{6}$ & $5.1 \%$ & $3.2 \%$ \\
\hline & & \\
\hline Average & $6.8 \%$ & $4.7 \%$ \\
\hline & & \\
\hline
\end{tabular}

Table 5

Model Fit: Actual vs Predicted Schooling Attainments

\begin{tabular}{|l|l|l|}
\hline Grade Level & Predicted (\%) & Actual \% \\
\hline & & \\
\hline Grade 6-8 & $6.0 \%$ & $3.0 \%$ \\
\hline Grade 9 & $7.7 \%$ & $4.7 \%$ \\
\hline Grade10 & $7.3 \%$ & $6.0 \%$ \\
\hline Grade11 & $8.5 \%$ & $7.5 \%$ \\
\hline Grade12 & $41.0 \%$ & $39.6 \%$ \\
\hline Grade13 & $6.9 \%$ & $7.0 \%$ \\
\hline Grade14 & $5.8 \%$ & $7.7 \%$ \\
\hline Grade15 & $1.7 \%$ & $2.9 \%$ \\
\hline Grade16 & $10.0 \%$ & $12.9 \%$ \\
\hline Grade17 + & $5.7 \%$ & $7.9 \%$ \\
\hline
\end{tabular}


Table 6 .

Correlations between Ability and the Average Returns to Schooling

\begin{tabular}{|l|c|c|}
\hline & & Correlations (P values) \\
\hline Partial Correlations & & \\
\hline School ab. and av. returns & $\operatorname{Corr}\left(v_{i}^{\xi}, \frac{\varphi\left(S_{i}\right)}{S_{i}} \mid v_{i}^{w}=\bar{v}^{w}\right)$ & $0.80(0.001)$ \\
\hline & & $-0.84(0.001)$ \\
\hline Market ab. and av. Returns & $\operatorname{Corr}\left(v_{i}^{w}, \frac{\varphi\left(S_{i}\right)}{S_{i}} \mid v_{i}^{\xi}=\bar{v}^{\xi}\right)$ & \\
\hline & & $0.95(0.001)$ \\
\hline Correlations & & \\
\hline School ab. and market ab. & $\operatorname{Corr}\left(v_{i}^{w}, v_{i}^{\xi}\right)$ & $0.23(0.001)$ \\
\hline & & \\
\hline Market ab. and av. returns & $\operatorname{Corr}\left(v_{i}^{w}, \frac{\varphi\left(S_{i}\right)}{S_{i}}\right)$ & $0.28(0.001)$ \\
\hline & & $\operatorname{Corr}\left(v_{i}^{w}, S_{i}\right)$ \\
\hline Market ab. and Schooling & & \\
\hline & & \\
\hline
\end{tabular}

Table 7

Estimates of the Average Return to Schooling

\begin{tabular}{|c|c|c|c|c|}
\hline & \multicolumn{2}{|c|}{ Average Returns } & \multicolumn{2}{|c|}{ Average Returns } \\
\hline & \multicolumn{2}{|c|}{ Computed from Grade 7} & \multicolumn{2}{|c|}{ Computed from Grade 10} \\
\hline Estimation Method & (grade 12) & (grade 16) & (grade 12) & (grade 16) \\
\hline Dynamic Prog. (ML) & 0.0071 & 0.0459 & 0.0177 & 0.0699 \\
\hline OLS (linear) & 0.0995 & 0.0995 & 0.0995 & 0.0995 \\
\hline OLS (Splines) & 0.0970 & 0.1129 & 0.0866 & 0.0942 \\
\hline
\end{tabular}

Note: The OLS estimates, reported in Table 7, are computed on the cross-section of 1990. Both OLS regressions contains experience and experience ${ }^{2}$. The OLS regression with splines contains 8 segments (grade 7 to 10 , grade 11 , grade 12 , grade 13 , grade 14 , grade 15 , grade 16 and grade 17 and more). 
Table 8

Estimates of the Wage Regression Function under an Alternative Model Specification

\begin{tabular}{|c|c|c|c|c|}
\hline \multicolumn{5}{|c|}{ Non-Parametric Mixture Model } \\
\hline \multicolumn{5}{|c|}{ (no Background Variable) } \\
\hline & & & & \\
\hline & Splines & Local. & Av, ret. & Av. ret \\
\hline & param (st error) & returns & (from gr. 7 ) & (from gr.10) \\
\hline \multicolumn{5}{|l|}{ Grade } \\
\hline grade7-10 & $0.0041(0.0009)$ & 0.0041 & 0.0041 & 0.0041 \\
\hline grade11 & $0.0093(0.0034)$ & 0.0134 & 0.0060 & 0.0088 \\
\hline grade12 & $0.0346(0.0027)$ & 0.0480 & 0.0130 & 0.0218 \\
\hline grade13 & $0.0135(0.0028)$ & 0.0615 & 0.0200 & 0.0318 \\
\hline grade14 & $0.0839(0.0034)$ & 0.1454 & 0.0359 & 0.0545 \\
\hline grade15 & $-0.0365(0.0034)$ & 0.1089 & 0.0437 & 0.0636 \\
\hline grade16 & $0.0034(0.0040)$ & 0.1123 & 0.0506 & 0.0705 \\
\hline grade17+ & $-0.0367(0.0040)$ & 0.0746 & 0.0528 & 0.0710 \\
\hline Exper. & $0.0973(0.0030)$ & & - & - \\
\hline Exper $^{2}$ & $-0.0039(0.0003)$ & & - & - \\
\hline log lik. & -14.1648 & - & - & - \\
\hline & & & & \\
\hline & & & & \\
\hline & & & & \\
\hline
\end{tabular}

Note: The mixture model is estimated under the assumption that the population is composed of 6 unknown types. 


\section{Liste des publications au CIRANO*}

Série Scientifique / Scientific Series (ISSN 1198-8177)

2002s-19 Unobserved Ability and the Return to Schooling / Christian Belzil et Jörgen Hansen

2002s-18 Auditing Policies and Information Systems in Principal-Agent Analysis / MarieCécile Fagart et Bernard Sinclair-Desgagné

2002s-17 The Choice of Instruments for Environmental Policy: Liability or Regulation? / Marcel Boyer, Donatella Porrini

2002s-16 Asymmetric Information and Product Differentiation / Marcel Boyer, Philippe Mahenc et Michel Moreaux

2002s-15 Entry Preventing Locations Under Incomplete Information / Marcel Boyer, Philippe Mahenc et Michel Moreaux

2002s-14 On the Relationship Between Financial Status and Investment in Technological Flexibility / Marcel Boyer, Armel Jacques et Michel Moreaux

2002s-13 Modeling the Choice Between Regulation and Liability in Terms of Social Welfare / Marcel Boyer et Donatella Porrini

2002s-12 Observation, Flexibilité et Structures Technologiques des Industries / Marcel Boyer, Armel Jacques et Michel Moreaux

2002s-11 Idiosyncratic Consumption Risk and the Cross-Section of Asset Returns / Kris Jacobs et Kevin Q. Wang

2002s-10 The Demand for the Arts / Louis Lévy-Garboua et Claude Montmarquette

2002s-09 Relative Wealth, Status Seeking, and Catching Up / Ngo Van Long, Koji Shimomura

2002s-08 The Rate of Risk Aversion May Be Lower Than You Think / Kris Jacobs

2002s-07 A Structural Analysis of the Correlated Random Coefficient Wage Regression Model / Christian Belzil et Jörgen Hansen

2002s-06 Information Asymmetry, Insurance, and the Decision to Hospitalize / Åke Blomqvist et Pierre Thomas Léger

2002s-05 Coping with Stressful Decisions: Individual Differences, Appraisals and Choice / Ann-Renée Blais

2002s-04 A New Proof Of The Maximum Principle / Ngo Van Long et Koji Shimomura

2002s-03 Macro Surprises And Short-Term Behaviour In Bond Futures / Eugene Durenard et David Veredas

2002s-02 Financial Asset Returns, Market Timing, and Volatility Dynamics / Peter F. Christoffersen et Francis X. Diebold

2002s-01 An Empirical Analysis of Water Supply Contracts / Serge Garcia et Alban Thomas

2001s-71 A Theoretical Comparison Between Integrated and Realized Volatilities Modeling / Nour Meddahi

\footnotetext{
* Consultez la liste complète des publications du CIRANO et les publications elles-mêmes sur notre site Internet :
} 
2001s-70 An Eigenfunction Approach for Volatility Modeling / Nour Meddahi

2001s-69 Dynamic Prevention in Short Term Insurance Contracts / M. Martin Boyer et Karine Gobert

2001s-68 Serial Cost Sharing in Multidimensional Contexts / Cyril Téjédo et Michel Truchon

2001s-67 Learning from Strike / Fabienne Tournadre et Marie-Claire Villeval

2001s-66 Incentives in Common Agency / Bernard Sinclair-Desgagné

2001s-65 Detecting Mutiple Breaks in Financial Market Volatility Dynamics / Elena Andreou et Eric Ghysels

2001s-64 Real Options, Preemption, and the Dynamics of Industry Investments / Marcel Boyer, Pierre Lasserre, Thomas Mariotti et Michel Moreaux

2001s-63 Dropout, School Performance and Working while in School: An Econometric Model with Heterogeneous Groups / Marcel Dagenais, Claude Montmarquette et Nathalie Viennot-Briot

2001s-62 Derivatives Do Affect Mutual Funds Returns : How and When? / Charles Cao, Eric Ghysels et Frank Hatheway

2001s-61 Conditional Quantiles of Volatility in Equity Index and Foreign Exchange Data / John W. Galbraith, Serguei Zernov and Victoria Zinde-Walsh

2001s-60 The Public-Private Sector Risk-Sharing in the French Insurance "Cat. Nat. System" / Nathalie de Marcellis-Warin et Erwann Michel-Kerjan

2001s-59 Compensation and Auditing with Correlated Information / M. Martin Boyer et Patrick González

2001s-58 Resistance is Futile: An Essay in Crime and Commitment / M. Martin Boyer

2001s-57 The Unreliability of Output Gap Estimates in Real Time / Athanasios Orphanides et Simon van Norden

2001s-56 Exact Nonparametric Two-Sample Homogeneity Tests for Possibly Discrete Distributions / Jean-Marie Dufour et Abdeljelil Farhat

2001s-55 Les coûts de la réglementation : une revue de la littérature / Robert Gagné, Paul Lanoie, Pierre-Carl Micheud et Michel Patry

2001s-54 Testing for structural Change in the Presence of Auxiliary Models / Eric Ghysels et Alain Guay

2001s-53 Environmental Regulation and Productivity: New Findings on the Porter Hypothesis / Paul Lanoie, Michel Patry et Richard Lajeunesse

2001s-52 The Aftermarket Performance of Initial Public Offerings in Canada / Maher Kooli et Jean-Marc Suret

2001s-51 Capital Structure and Risk Management / Karine Gobert

2001s-50 The Underpricing of Initial Public Offerings: Futher Canadian Evidence / Maher Kooli et Jean-Marc Suret

2001s-49 How Innovative Are Canadian Firms Compared to Some European Firms? A Comparative Look at Innovation Surveys / Pierre Mohnen et Pierre Therrien

2001s-48 A Tale of Two Ports / Ngo Van Long et Kar-yiu Wong

2001s-47 Wage Policy of Firms: An Empirical Investigation / Stéphanie Lluis

2001s-46 Forecasting Some Low-Predictability Time Series Using Diffusion Indices / Marc 